\title{
The vertical distribution and diurnal migration of some zooplankton in the Bay of Eilat (Red Sea)
}

\author{
H.-E. SCHMIDT \\ 1. Zoologisches Institut der Universität Wien, Lebrkanzel für Meeresbiologie; \\ Wien, Austria
}

\begin{abstract}
KURZFASSUNG: Die vertikale Verteilung und tägliche Wanderung einiger Zooplankter in der Bucht von Eilat (Rotes Meer). Im Sommer 1970 wurden zum Studium der vertikalen Verteilung und täglichen Vertikalwanderung des Zooplanktons in der Bucht von Eilat (Rotes Meer) Planktonfänge durchgeführt. Während eines Sammelprogramms von 24 Stunden im Juni wurden Schließnetzfänge alle zwei Stunden und während des Sonnenauf- und -unterganges jede Stunde aus folgenden Tiefenbereichen entnommen: $300-200 \mathrm{~m}, 200-150 \mathrm{~m}, 150-100 \mathrm{~m}, 100$ bis $75 \mathrm{~m}, 75-50 \mathrm{~m}, 50-25 \mathrm{~m}$ und $25 \mathrm{~m}$ bis zur Wasseroberfläche. Die Dichte des Planktons (das "displacement volume" aller Fänge einer bestimmten Tiefenschicht wurde addiert) nimmt bis in die Tiefe von $100 \mathrm{~m}$ langsam, danach schnell ab. Die größte Dichte liegt zwischen 25 und $50 \mathrm{~m}$. Die Anzahl der Copepoden, Gastropoden und Chaetognathen je Planktonprobe nimmt mit zunehmender Meerestiefe ab, im Falle der Gastropoden und Chaetognathen sogar von 25-m-Stufe zu 25-m-Stufe um 50\%. Die Appendicularien sind zwischen 25 und $50 \mathrm{~m}$ Tiefe am häufigsten; ihre Dichte nimmt nach oben und nach unten deutlich $a b$. Es wird versucht, die tägliche Vertikalwanderung zu beschreiben. Alle vier untersuchten Gruppen meiden das Tageslicht; sie halten sich am Tage vorzugsweise unterhalb $50 \mathrm{~m}$ auf. Bemerkenswert sind die hohen Dichten der Gastropoden, Chaetognathen und Appendicularien während des Sonnenaufgangs und -untergangs in den oberen Wasserschichten.
\end{abstract}

\section{INTRODUCTION}

Our knowledge of the Red Sea plankton is rather poor (HaLIM 1969), especially in regard to ecological problems. Only a few investigations on the vertical distribution and diurnal migration of plankton have been carried out in that area (VINOGRADov 1968). Hydrographical observations from the Bay of Eilat (OREN 1962, SCHMIDT 1973) show a nearly homogenous water body in respect of temperature and salinity from the water surface to the sea bottom. First results on the vertical distribution and diurnal migration of Hydromedusae in this region have been provided by ScHMiDT (1973).

The following results on some organisms of the zooplankton - especially Copepoda, Chaetognatha, Gastropoda and Appendicularia - give a first survey on their distribution and migration in the Bay of Eilat. The fact that these groups have not been separated into species leads to some generalizations, but also facilitates further investigations in this field. 


\section{MATERIAL AND METHODS}

The material was collected during a sampling programme in the Bay of Eilat, about $1000 \mathrm{~m}$ south of the Marine Biological Laboratory in the middle of the Gulf. The programme lasted from 18th June, 1970, 7 a.m. to 19 th June, 7 a.m. The following depth ranges were filtered by a modified Nansennet $\left(200 \mu\right.$ mesh width, $0.25 \mathrm{~m}^{2}$ mouth area) every 2 hours, with the exception of dawn and dusk, when the samples were taken hourly: 300 to 200,200 to 150,150 to 100,100 to 75,75 to 50,50 to 25 and $25 \mathrm{~m}$ to the surface. The ranges were chosen after checking more than 200 vertical hauls from different depths in this area.

The plankton was placed in bottles and immediately fixed with $4 \%$ formalin. After measuring the displacement volume, the individuals were counted without splitting the sample. For detailed information about material and methods consult SchmidT (1973).

To find out the vertical distribution, volume and number of individuals of the 14 samples which were taken from every depth range during the 24 hours are totaled. In this case day-samples are not differentiated from night-samples. All quantities are computed on the basis of a filtered water column of $50 \mathrm{~m}$ to make them comparable. Because no flow meter was available, only the theoretical water mass filtered is known.

In order to assess diurnal migrations, the number of individuals per sample was determined. Only the upper $100 \mathrm{~m}$ are considered because the plankton concentration in greater depths is not high enough to obtain statistically significant results. Therefore, numbers are given for every $25 \mathrm{~m}$ of filtered water column. The full hour only in which the sample was taken is indicated in the figures.

\section{RESULTS}

\section{Zooplankton volume}

The highest concentration of zooplankton (Fig. 1) occurs between 25 and $50 \mathrm{~m}$ depth. The concentration decreases slowly to a depth of $100 \mathrm{~m}$, and then more rapidly. The value between 200 and $300 \mathrm{~m}$ is only $10 \%$ of that between 25 and $50 \mathrm{~m}$. There is no significant difference between the ranges above $75 \mathrm{~m}$ depth.

\section{Copepoda}

The number of copepods per unit (Fig. 2) is rather high in the upper water layers with an average of 1800 individuals per sample ( $50 \mathrm{~m}$ water column). It then decreases rapidly between 25 and $50 \mathrm{~m}(1280)$, and between 50 and $75 \mathrm{~m}(720)$, and slowly below $75 \mathrm{~m}$ depth (500 between 75 and 100,340 between 100 and 150, 220 between 150 and 200 and 145 between 200 and 300 ).

In total, the Copepoda show no significant diurnal migration, except for the upper water layers around noon. For detailed analysis, it seems important to divide this group into its species. 


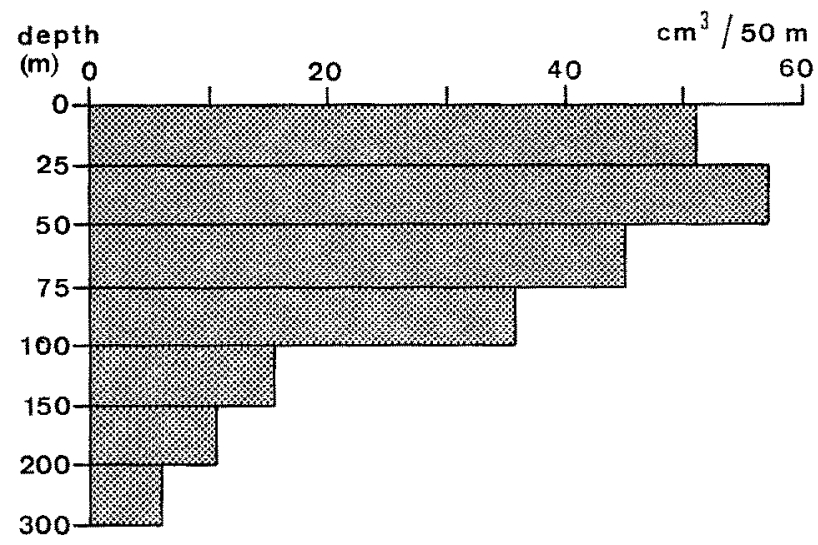

Fig. 1: Vertical gradient in concentration of zooplankton expressed in $\mathrm{cm}^{3}$ displacement volume, computed on the basis of a $50 \mathrm{~m}$ water column filtered

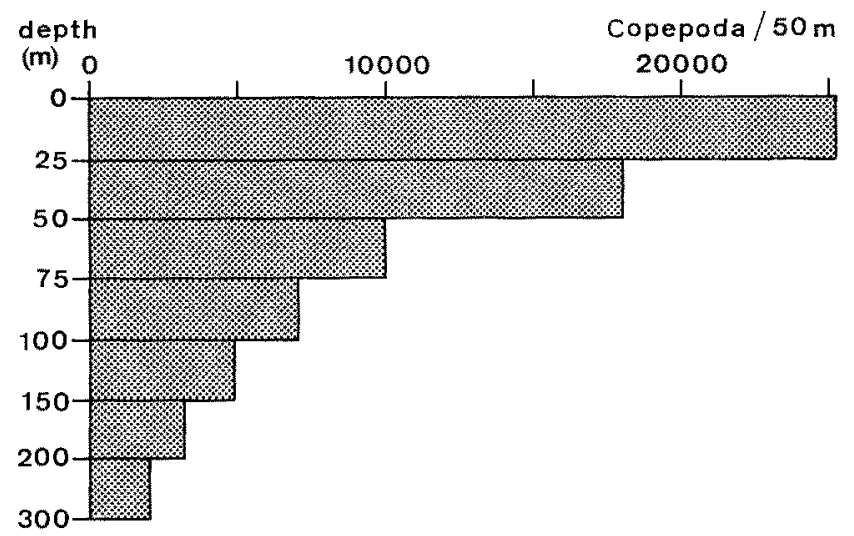

Fig. 2: Vertical distribution of Copepoda. Numbers of specimens computed on the basis of a $50 \mathrm{~m}$ water column filtered

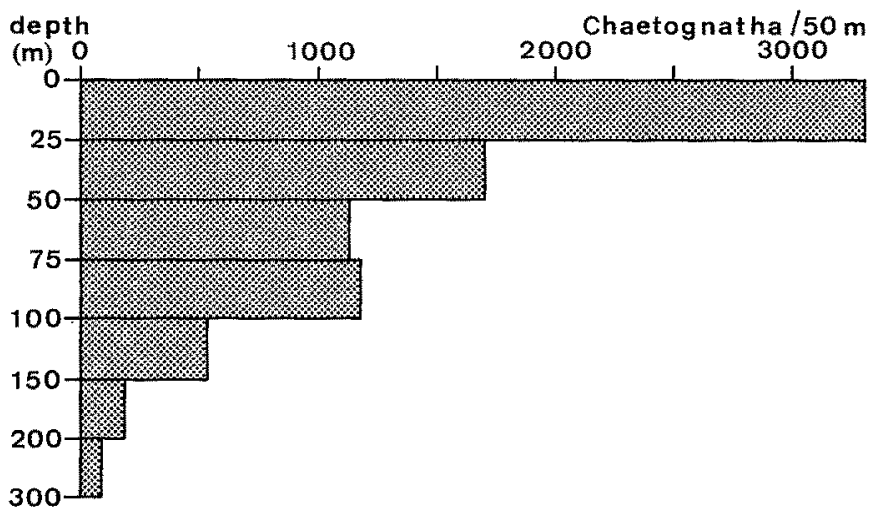

Fig. 3: Vertical distribution of Chaetognatha. Numbers of specimens computed on the basis of a $50 \mathrm{~m}$ water column filtered 


\section{Chaetognatha}

Chaetognatha are most abundant between surface and $25 \mathrm{~m}$ depth (Fig. 3). Their density is reduced to $50 \%$ between 25 and $50 \mathrm{~m}$ (on an average 230 to 115 individuals per plankton sample in $50 \mathrm{~m}$ water column). The number of Chaetognatha remains constant between 50 and $100 \mathrm{~m}$, then decreases rapidly.

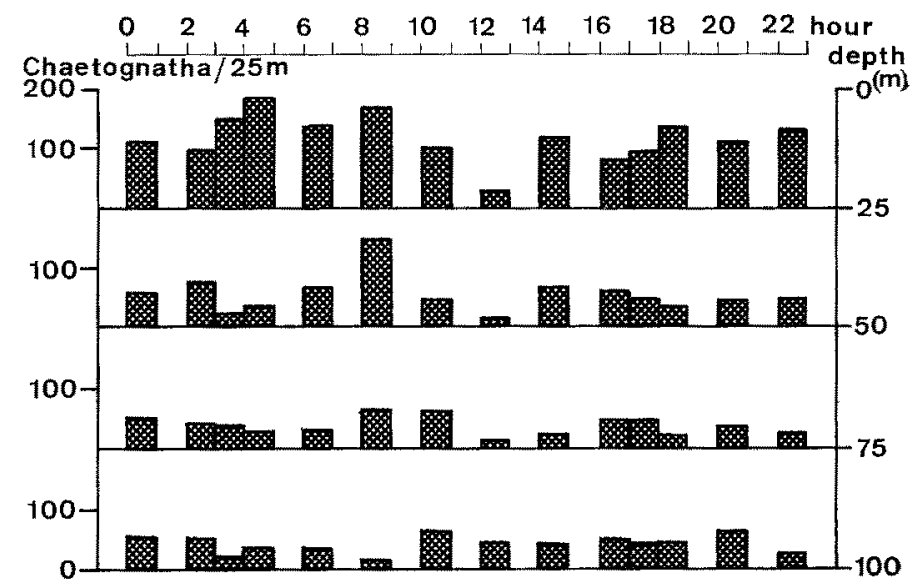

Fig. 4: Diurnal migration of Chaetognatha. Number of specimens per plankton sample computed on the basis of a $25 \mathrm{~m}$ water column filtered

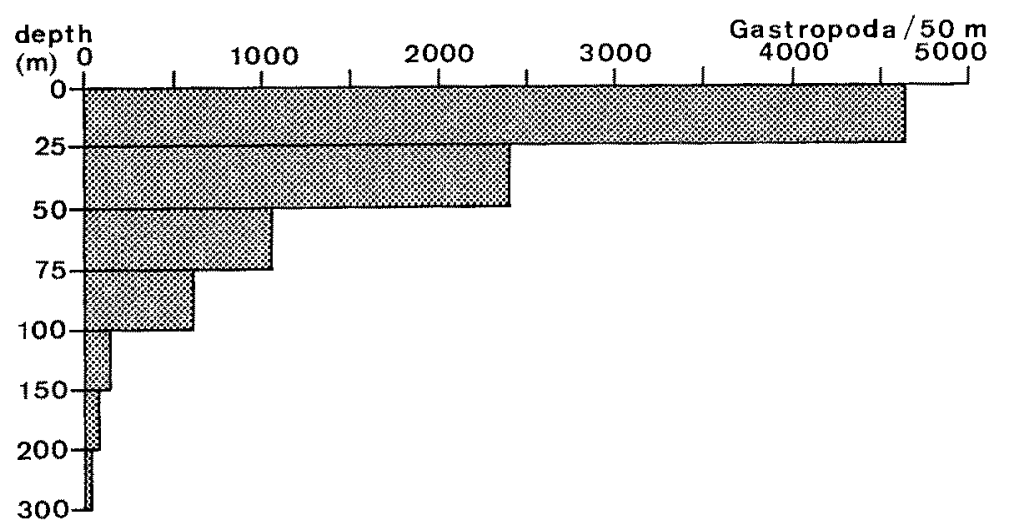

Fig. 5: Vertical distribution of Gastropoda. Numbers of specimens computed on the basis of a $50 \mathrm{~m}$ water column filtered

The number of individuals of Chaetognatha per plankton sample (Fig. 4) is low between the surface and $75 \mathrm{~m}$ depth around noon; it is high in the upper $25 \mathrm{~m}$ during the night, between 25 and $50 \mathrm{~m}$ around dawn and dusk (4.55 a.m./6.10 p.m.), and below $75 \mathrm{~m}$ during daytime. 
Gastropoda

The larvae of Gastropoda (Fig. 5) show similar vertical distributions to the Chaetognatha (Fig. 3): Their density is reduced by $50 \%$ every $25 \mathrm{~m}$. The numbers of individuals per plankton sample (based on $50 \mathrm{~m}$ water column) are: $330(25 \mathrm{~m}$ to surface), $170(50$ to $25 \mathrm{~m}), 72(75$ to $50 \mathrm{~m}), 43(100$ to $75 \mathrm{~m}), 10(150$ to $100 \mathrm{~m}), 4.5$ (200 to $150 \mathrm{~m}$ ) and $1.6(300$ to $200 \mathrm{~m})$.

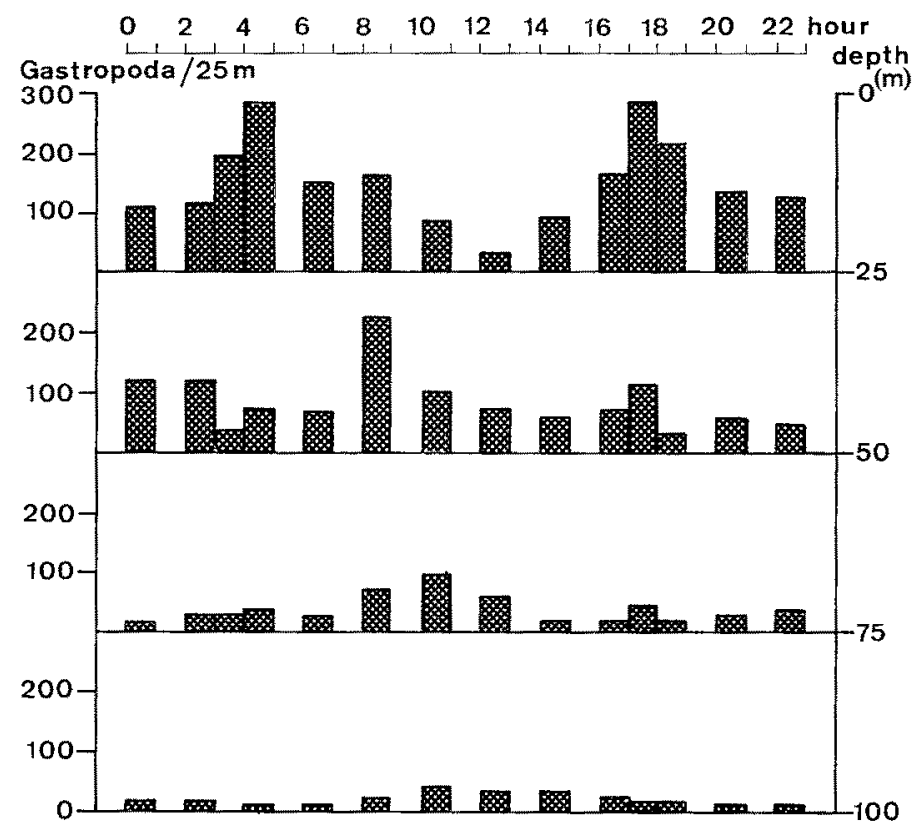

Fig. 6: Diurnal migration of Gastropoda. Number of specimens per plankton sample computed on the basis of $25 \mathrm{~m}$ water column filtered

The Gastropoda show high values at the time of sunset and sunrise in the upper $25 \mathrm{~m}$ (Fig. 6). This trend continues down to $50 \mathrm{~m}$; below that we found the highest concentration during daytime.

\section{Appendicularia}

The Appendicularia (Fig. 7) exhibit their greatest density between 25 and $50 \mathrm{~m}$ depth; above that layer, the concentration is reduced to $50 \%$ (from 100 to 52 specimens per sample). The concentration decreases rapidly between 50 and $75 \mathrm{~m}$ depth and stays nearly constant between 75 and $150 \mathrm{~m}$. Below $150 \mathrm{~m}$, only a few Appendicularia are present ( 9 individuals per sample).

The number of specimens per sample obtained during 24 hours (Fig. 8) shows high values in the upper $25 \mathrm{~m}$ during dawn and dusk, between 25 and $50 \mathrm{~m}$ during night, 


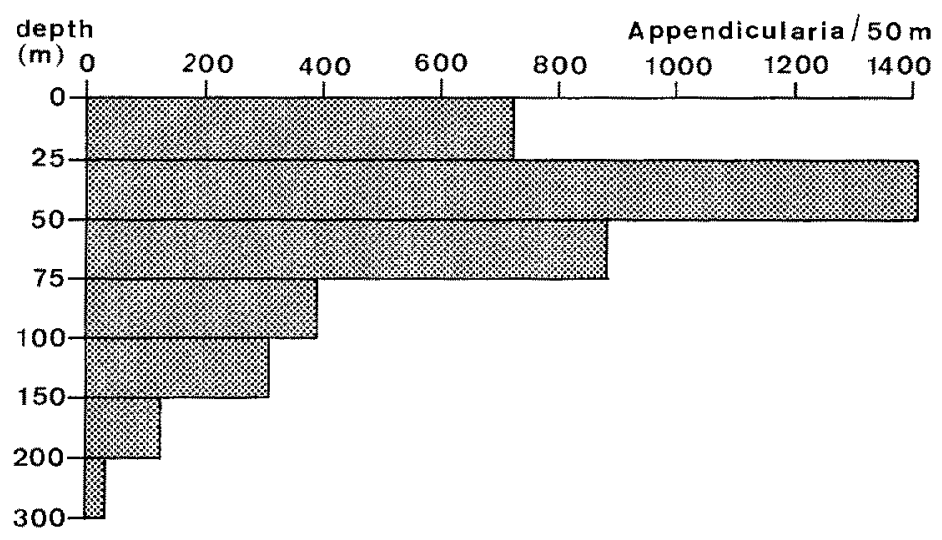

Fig. 7: Vertical distribution of Appendicularia. Number of specimens computed on the basis of a $50 \mathrm{~m}$ water column filtered

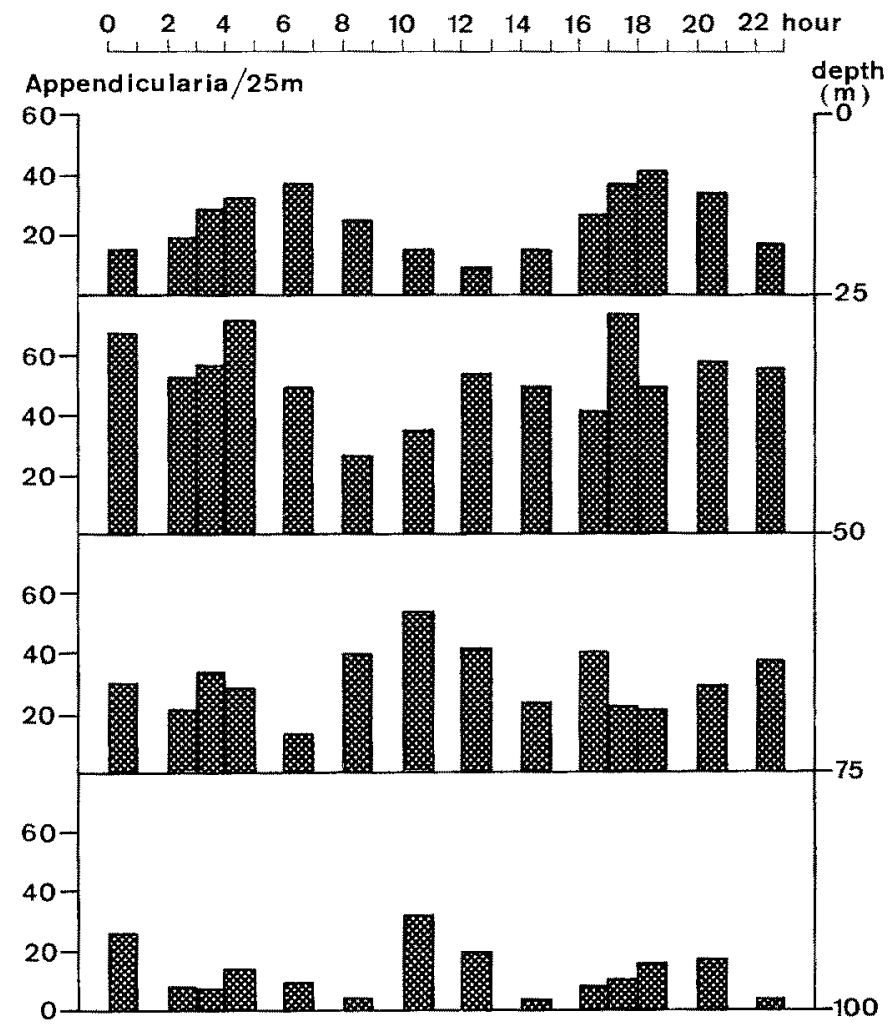

Fig. 8: Diurnal migration of Appendicularia. Number of specimens per plankton sample computed on the basis of a $25 \mathrm{~m}$ water column filtered 
and below $50 \mathrm{~m}$ during daytime. Comparatively low values were found in layers down to $50 \mathrm{~m}$ during daytime.

\section{DISCUSSION}

Different methods of plankton sampling and of counting the individuals may yield different results. This fact should be ignored in the present context because the percentage variation determined remains theoretically the same. However, the systematical groupings employed (Copepoda, Gastropoda, Appendicularia and Chaetognatha) may mask differences in species behaviour. Therefore, the results obtained can only indicate general trends and provide basic hints for further research in the area investigated which is characterized by a water body with nearly uniform conditions. Lack of data prevents a comparison between the chemical composition of the water and the behaviour of zooplankton in the Bay of Eilat.

The density of plankton animals decreases significantly with increasing water depth. Investigators who study vertical plankton distribution frequently use hauls over $50 \mathrm{~m}$ or more. These distances are too large to reveal details in distribution patterns. If the concentrations found in the $25-\mathrm{m}$ steps are added to give $50-$ or $100-\mathrm{m}$ steps, no variations during the 24 -hour intervals can be detected.

The number of individuals per sample decreases with increasing depth in Copepoda, Gastropoda and Chaetognatha; however, the volume of zooplankton obtained per sample shows the highest values between 25 and $50 \mathrm{~m}$ depth. This result may be due to the fact that in some of the systematical groupings employed, young specimens live closer to the surface, while larger ones occur deeper down (ALVARINo 1967, VINoGRADOV 1968).

Avoidance of light by zooplankton can again be demonstrated, but there is no explanation at hand for the preference of the upper layers during dawn and dusk. This behaviour was observed in the hydromedusa Aglaura hemistoma PÉron \& Lesueur, but not in Liriope tetraphylla Chamisso \& Eysenhardt (Schmidt 1973). No conclusions can be drawn from the results as to distributional relationships between Aglaura bemistoma and the Chaetognatha, Gastropoda and Appendicularia investigated.

The high concentrations of Appendicularia found between 25 and $50 \mathrm{~m}$ are in contrast to results reported by FENAux (1968a, 1968b) from the Mediterranean Sea, also based on $25-\mathrm{m}$ tows. A separation into species is necessary for more detailed investigations.

\section{SUMMARY}

1. During summer 1970, plankton samples were taken in the Bay of Eilat (Red Sea) to study vertical distributions and diurnal migrations of zooplankton. In June, a collecting programme was conducted over 24 hours. Samples were taken with a closing net every 2 hours, at dawn and dusk every hour. The following depth ranges were 
sampled: 300 to $200 \mathrm{~m}, 200$ to $150 \mathrm{~m}, 150$ to $100 \mathrm{~m}, 100$ to $75 \mathrm{~m}, 75$ to $50 \mathrm{~m}, 50$ to $25 \mathrm{~m}$, and $25 \mathrm{~m}$ to water surface.

2. The plankton concentration (accumulated displacement volume of all samples from a certain depth) decreases slowly from the surface to $100 \mathrm{~m}$, then rapidly to $300 \mathrm{~m}$ depth. Maximum concentrations are found between 25 and $50 \mathrm{~m}$.

3. In Copepoda, Gastropoda and Chaetognatha, the concentration of individuals decreases with increasing depth. Gastropoda and Chaetognatha may exhibit reductions of $50 \%$ over a single $25-\mathrm{m}$ step. The Appendicularia concentration is high between 25 and $50 \mathrm{~m}$; it decreases towards the surface and with increasing depth.

4. As far as it is possible to ascertain the diurnal vertical migrations of these animal groups without separation into species, the four groups can be said to avoid the upper layers during daytime; during this time they occur below $50 \mathrm{~m}$. Around sunset and sunrise, gastropods, chaetognaths and appendicularians tend to accumulate above $25 \mathrm{~m}$.

Acknowledgements. I am indebted to the staff of the Marine Biological Laboratory in Eilat (Israel), especially the late Prof. Dr. H. Sternitz. I sincerely thank Dr. J. OTr (Vienna) and R. MACHAN (Vienna) for critically reading the manuscript. $I$ also wish to express my gratitude to L. Hugh-Games (Eilat) and A. Bleichner (Gießen) for tednical help. Financial support was provided by "Deutscher Akademischer Austauschdienst" (DAAD) and Deutsche Forschungsgemeinschaft (DFG).

\section{LITERATURE CITED}

Alvarino, A., 1967. Bathymetric distribution of Chaetognatha, Siphonophora, Medusae, and Ctenophorae off San Diego, California. Pacif. Sci. 21, 474-485.

Fenaux, R., 1968a. Distribution verticale de la fréquence chez quelques Appendiculaires. Rapp. P.-v. Réun. Commn int. Explor. scient. Mer Méditerr. 19, 513-515.

- 1968b. Quelques aspects de la distribution verticale chez les Appendiculaires en Méditerranée. Cah. Biol. mar 9, 23-29.

Halim, Y., 1969. Plankton of the Red Sea. Oceanogr. Mar. Biol. 7, 231-275.

Oren, O. H., 1962. A note on the hydrography of the Gulf of Eylath. Bull. Sea Fish. Res. Stn Israel 30, 3-14.

SCHMDT, H.-E., 1973. Die vertikale Verteilung und tägliche Migration der Hydromedusen (Hydrozoa: Coelenterata) in der Bucht von Eilat (Rotes Meer). Mar. Biol. 18, 61-68.

Vinogradov, M. E., 1968. Vertical distribution of the oceanic zooplankton. Israel Program for Scientific Transl., Jerusalem, 339 pp.

Author's address: Dr. H.-E. ScHMDT

I. Zoologisches Institut der Universität Wien

Lehrkanzel für Meeresbiologie

A-1090 Wien

Währinger Str. $17 / 6$

Austria 